\title{
Price flexibility and output volatility: the case for flexible exchange rates
}

\author{
Giovanni Barone-Adesi \\ University of Alberta, Edmonton, Alberta T6G2R6. Canada \\ AND \\ Bernard YeUnG* \\ University of Michigan, Ann Arbor, Michigan 48109, USA
}

\begin{abstract}
This paper uses descriptive statistics and regression analyses to examine the relationship between exchange rate variability and output volatility in developed countries based on 1961 to 1984 data. The results indicate that a flexible exchange rate system is associated with less, not more, dispersion in output growth across industrialized countries despite a more turbulent global environment. Also, countries which have more exchange rate volatility experience less output volatility. The relationship appears not to be spurious. The results are consistent with the idea that an increase in price flexibility does not destabilize output.
\end{abstract}

This paper examines the historical relationship between exchange rate variability and output volatility using multiple country data. The objective is to determine empirically (i) whether flexible exchange rates help an economy to absorb shocks, or make matters worse, and (ii) whether output growth becomes more, or less, diverse across countries after a switch to a flexible exchange rate system.' The authors also hope that the results shed light on the relationship between price flexibility and output stability.

This research is inspired by the assertion (Friedman, 1953) that a flexible exchange rate system is better than a fixed exchange rate system in helping an economy to adjust to shocks. It is also inspired by the assertion (Kindleberger, 1969 ) that flexible exchange rates lead to more segmentation of the world market for goods and capital. After more than one and a half decades of floating exchange rate experience, the time has come to examine the empirical validity of these assertions.

This research is also stimulated by the recent articles of De Long and Summers (1986b) and Driskill and Sheffrin (1986), which discuss the relationship between price flexibility and the stability of output. The understanding of this issue can be improved by using empirical evidence. We believe that a reliable piece of empirical

\footnotetext{
* We benefited from discussions with Gunter Dufey, Dave Jobson. Roger Kormendi. James Lothian. Philip Meguire, and Rolf Mirus. Comments from an anonymous referee were also helpful. All errors are ours. Chad Nehrt and Lisa Strang provided excellent research assistance.
} 
evidence became available when the industrialized economies switched from a fixed to a flexible exchange rate regime.

The data set is composed of statistics from the industrialized countries. The time period is from 1961 to 1984 ; thus, it includes more than a decade both before and after the industrialized economies switched from a fixed to a flexible exchange rate regime in the early 1970 s. Cross-country comparisons reveal that, after switching to a flexible exchange rate regime, the ind ustrialized countries exhibited considerably less divergence in output growth. Time series data show that the volatility of individual countries' output in the flexible exchange rate regime is not significantly different from that in the fixed exchange rate regime.

The regression analyses suggest that the increase in coherence in output growth across countries may be more than spuriously related to the increase in exchange rate flexibility. For individual countries, the correlation between the variations in output growth and the variations in exchange rate (both real and nominal) changes switch from positive in the fixed rate regime to negative in the flexible rate regime after a transitional period. The negative relationship in the flexible rate period is due to two effects. First, exchange rate volatility is negatively correlated with the variations in country-specific residual growth. Second, exchange rate volatility is negatively correlated with the impact of fluctuations in global output growth on domestic output growth.

The results indicate that the flexible exchange rate system appears to have played a role in leading to more coherent output growth across countries. Also, it has apparently helped the industrialized economies to adapt to shocks rather than contributing to more output volatility. It is believed that the results are consistent with the view that an increase in price flexibility is not destabilizing.

The motivation for this paper is presented in Section 1. The descriptive characteristics of the data are reported in Section II and the regression analyses in Section III. Section IV outlines conclusions.

\section{Motivation}

More than 30 years ago, Milton Friedman (1953, p. 202), in arguing for flexible exchange rates, stated that, 'The major aim of policy is not to prevent (such) changes from occurring but to develop an efficient system of adapting to them.' He suggested that a flexible exchange rate system is such a system. He claimed further that (p. 163), "The exchange rate is therefore potentially an extremely sensitive price. Changes in it occur rapidly, automatically, and continuously and so tend to produce corrective movements ...' Thus, the presumption is made that flexible exchange rates help an economy to absorb shocks.

It is now well known that the relative ability of a flexible and a fixed exchange rate system to absorb shocks depends on the origin and the nature of a shock. Flexible exchange rates are more helpful in absorbing domestic real shocks, while fixed exchange rates perform better in dealing with domestic monetary shocks. When it comes to foreign shocks, flexible exchange rates are no longer regarded as having an insulation advantage, especially now that capital markets have generally become more integrated. (See Marston, 1985, Section 6, for an informative discussion.) It is also recognized that shocks are transmitted differently under the two different exchange rate systems.

Economies are continuously subject to real and monetary shocks originating 
both at home and abroad. Thus, in general, the unconditional ability of a fixed and a flexible exchange rate system in absorbing shocks is an empirical issue. It is, therefore, desirable to document empirically the relationship between variations in exchange rate changes and output changes in both fixed and flexible exchange rate periods.

It has also been suggested that flexible exchange rates lead to segmentation of economies. For example, Kindleberger (1969, p. 99), in arguing for fixed exchange rates, stated that, 'The main case against flexible exchange rates is that they break up the world market. There is no one money which serves as a medium of exchange .... Under a system of freely fluctuating exchange rates, the world market for goods and capital would be divided.'

De Grauwe (1988, p.69) suggests a political economy explanation for the possibility that exchange rate variability impedes export growth: 'Protectionist legislation passed when the currency tended to be overvalued is kept in place when the currency is in the undervaluation part of the cycle. If such asymmetries are present, then swings in the real exchange rates will lead to a trend-like increase in protectionism and will negatively affect international trade. 'Darby and Lothian (1989) document that flexible exchange rates have been accompanied by greater long-run monetary policy independence. It is wondered if this greater monetary independence would imply more, or less, divergent output performance across countries.

It is, however, not clear if flexible exchange rates definitely lead to more segmentation of economies. First, there is no reason to believe that transmission of economic changes is less fluent in a flexible exchange rate system than in a fixed exchange rate system. Second, without the need to defend pegged rates, governments may be less inclined, and have less excuse, to impose barriers to the movement of goods and capital.

It is difficult to test for differences in the degree of economic integration under a fixed and a flexible exchange rate system. This paper, therefore, undertakes a less ambitious exercise: it attempts to document the empirical relationship between the degree of divergence in output growth across nations and exchange rate variability. The authors believe such results can shed some light on the economic integration issue.

Evidence of the relationships between volatility in exchange rates and output growth, and between exchange rate variability and cross-country coherence in output growth will prove particularly useful. Such information can provide important guidance for theoretical development. It also can prove useful for policy-makers. Even in a generally flexible exchange rate regime, the degree of flexibility in exchange rates varies across nations. The volatility of exchange rates can be influenced by government policies and is often an explicit focus of policy-makers. It is important to have empirical information on the relationship between exchange rate flexibility and output volatility to guide policy decisions.

The results also provide empirical evidence of the impact of an increase in price flexibility on output stability, an issue that has been hotly debated recently. While there is a presumption in economics that output is more stable in a more flexible price system, it has, nevertheless, been argued that rapid price movements will both cause and magnify shocks, making output more volatile. This can be due to the influence of expectations and serial interdependence in economic behavior. Irving Fisher (1923, p. 1027) argued that, 'Rapidity of price movement during 1914-1922 
seems to account, almost completely, for the ups and downs of business.' More recently, De Long and Summers (1986a) suggest that the decrease in output volatility in the post-war US economy is due to an increase in price rigidity.

There is no firm theoretical conclusion on the sign of the impact of an increase in price flexibility on output stability. Relying on numerical simulations, De Long and Summers (1986b) show that an increase in price flexibility can often turn out to be destabilizing. However, in another study also based on mathematics and numerical simulation, Driskill and Sheffrin (1986) conclude that price level flexibility is likely to be stabilizing.

The economic models as well as the parameter values used by De Long and Summers (1986a) and Driskill and Sheffrin (1986) are not identical. ${ }^{2}$ Therefore, the contradiction in their results points to the fact that the relationship between price level flexibility and output stability is dependent upon the structure of the underlying economy as well as on the value of important economic parameters. ${ }^{3}$ In other words, the influence of price flexibility on output stability is ultimately an empirical matter.

Contrasting the relationship between exchange rate variability and output volatility during a fixed and a flexible exchange rate regime, empirical evidence is provided regarding the behavior of output before and after a significant change in price level flexibility. As documented in Mussa (1986), both real and nominal exchange rates are a lot more volatile in a flexible exchange rate regime than in a fixed exchange rate regime. Since real exchange rates are the relative prices of national goods, the implication is that relative prices of national output are more volatile in a flexible exchange rate regime than in fixed exchange rate regime. Also, as will be shown later, there seems to be evidence that the flexibility of the internal price $(\mathrm{CPI})$ of an economy is positively correlated with the volatility of its exchange rates. Therefore, evidence on the relationship between the volatility of exchange rates and the volatility of output before and after the industrialized economies switched from a fixed to a flexible exchange rate regime can shed light on the impact of an increase in price flexibility on output stability. ${ }^{4}$

\section{Results from descriptive statistics}

A major difficulty with an investigation of the relationship between the flexibility of exchange rates and the volatility of output is that only about 15 years of post-war experience with floating exchange rates are available. Reliable output data are often only available in annual series. Even in the instances in which reliable quarterly data are available, at most roughly 60 data points are obtained. Such short series inevitably generate only a very limited set of volatility measures, making a time series study impractical. This paper, therefore, focuses on differences across countries. The implicit assumption, of course, is that the functional relationship between exchange rate variations and output volatility is homogeneous across the countries in our sample.

Hence, this paper concentrates on 17 industrialized countries with fairly similar economies: Japan, Austria, Australia, Belgium, Canada, Denmark, Finland, France, West Germany, Ireland, Italy, the Netherlands, Norway, Spain, Sweden, Switzerland, and the United Kingdom. ${ }^{5}$ The US dollar and the basket of consumption goods in the USA are chosen as the denominator in defining nominal and real exchange rates. Nominal exchange rate series of these countries are 
extracted from the OECD Economic Outlook (1985, 1987, both on p. 19). Consumer price indices (CPI) and annual real gross domestic product (GDP) growth rates of these countries are taken from the International Financial Statistic Yearbook (International Monetary Fund, 1986, pp. 110-111 and pp. 152-153, respectively).

Figures 1 and 2 show the time scries plots of the cross-country means and variances of the annual real GDP growth rates from 1961 to 1984, respectively. The well-known decline in output growth in the 1970s and the early 1980s is readily apparent in Figure 1. The average of these cross-country means of output growth decreased from 0.0523 in the 1961-72 period (a fixed exchange rate regime) to 0.0255 in the 1973-84 period (a flexible exchange rate regime). To preserve the focus of this paper, the discussion of this observation is postponed until the final section.

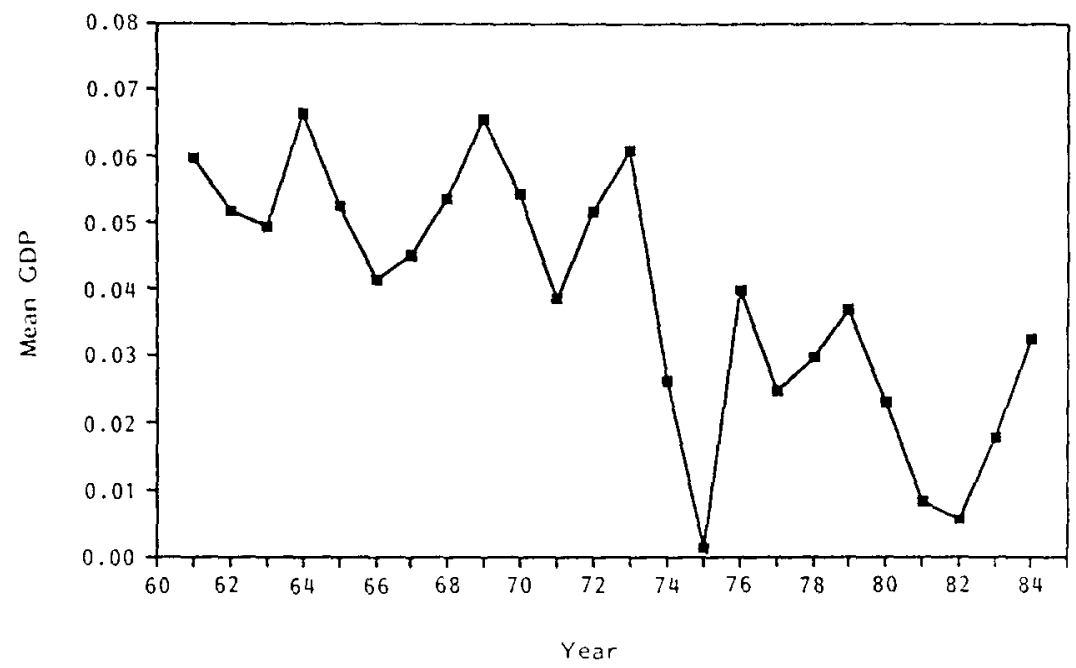

Figure 1. Cross country mean of annual real GDP growth 1961-84.

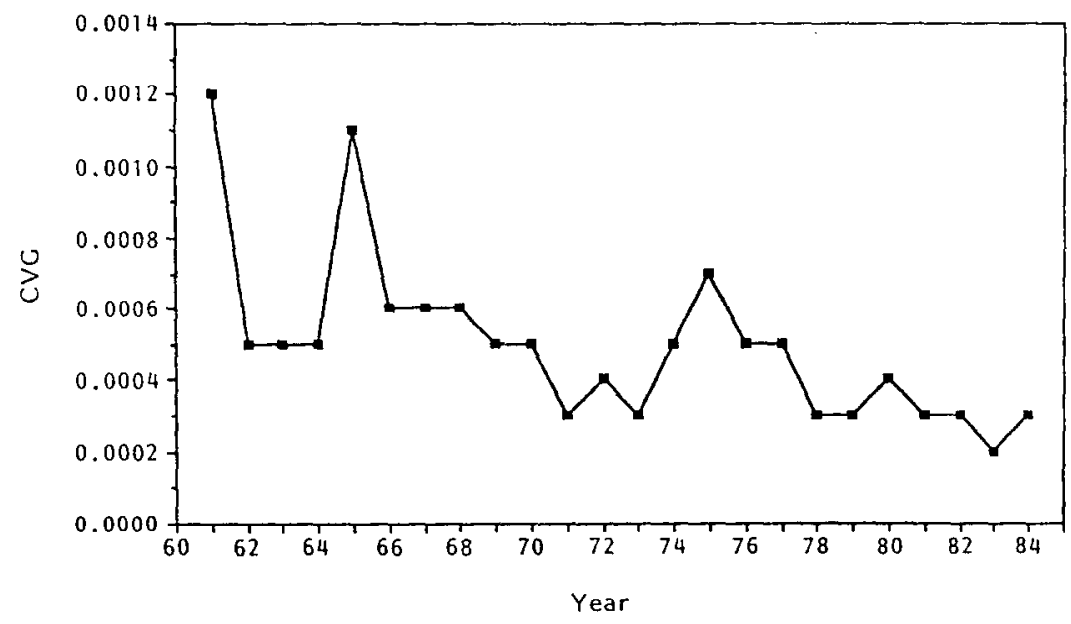

FIGURE 2. Cross country variance of annual real GDP growth 1961-84. 
The surprise in Figure 2 is the noticeable decline in the cross-country variance of output growth. The average of these variances from 1961 to 1972 (a fixed exchange rate regime) is 0.00061 while the same average for the remaining years (a flexible exchange rate regime) is only 0.00038 . It would be expected that this volatility measure would reflect the well-publicized economic turbulence of the $1970 \mathrm{~s}$ and exhibit an upward trend.

Figures 3 and 4 show the time series plots of the cross-country means and variances of the annual changes (first log-difference) in the nominal exchange rates from 1961 to 1984, respectively. Figures 5 and 6 show the same time series plots for the real exchange rates. The real exchange rate is defined as the price of a local

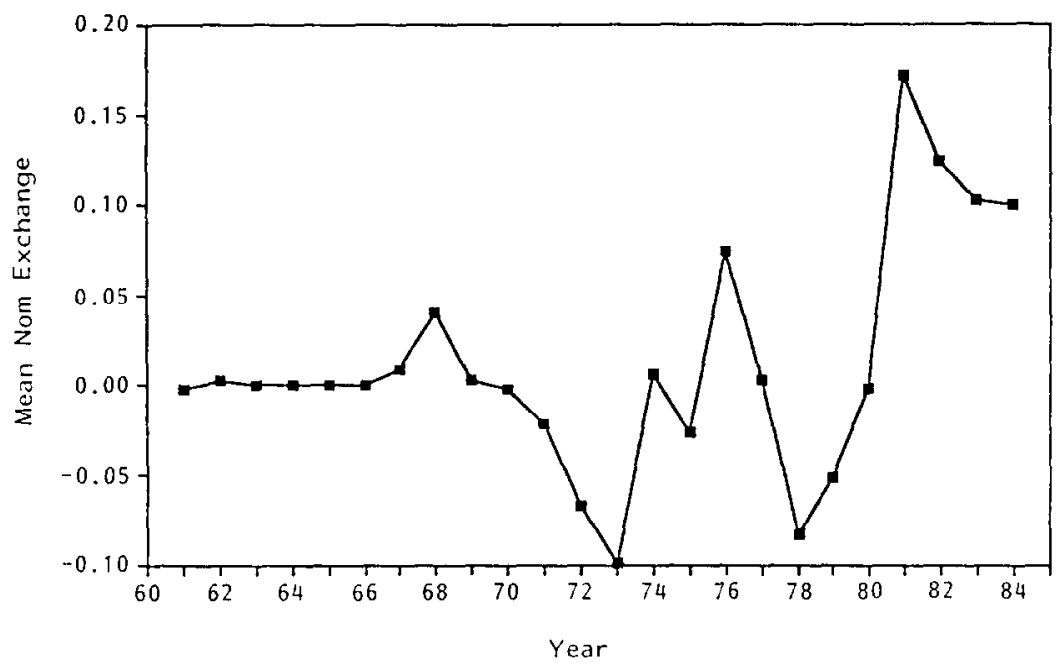

FIGURE 3. Cross country mean of the annual change in the nominal exchange rates $1961-84$.

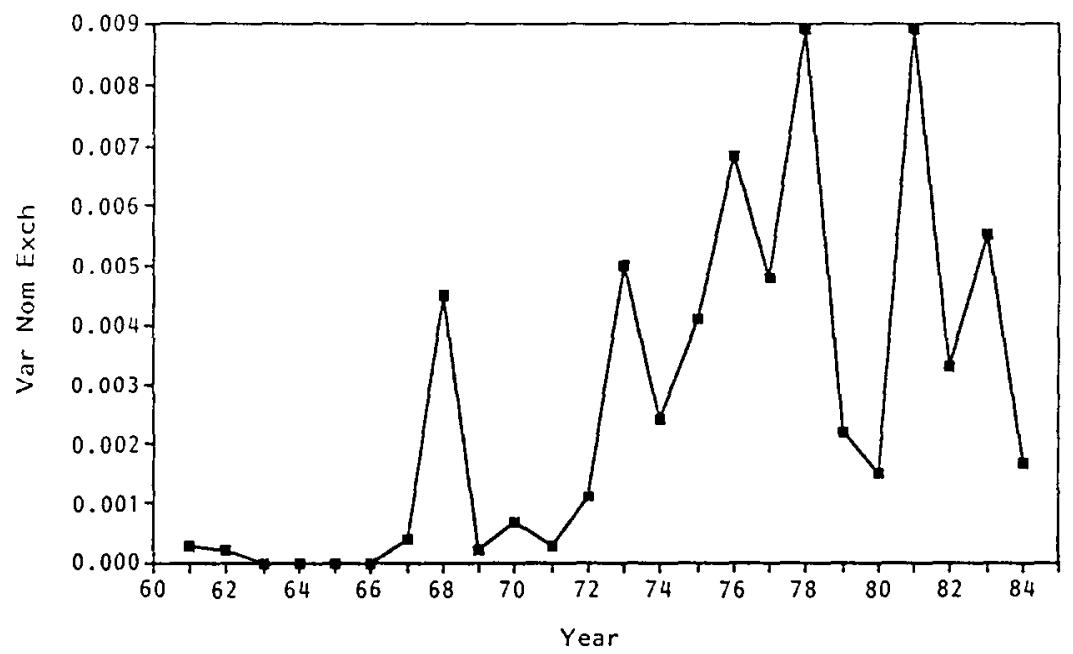

FIGURE 4. Cross country variance of the annual change in the nominal exchange rates $1961-84$. 


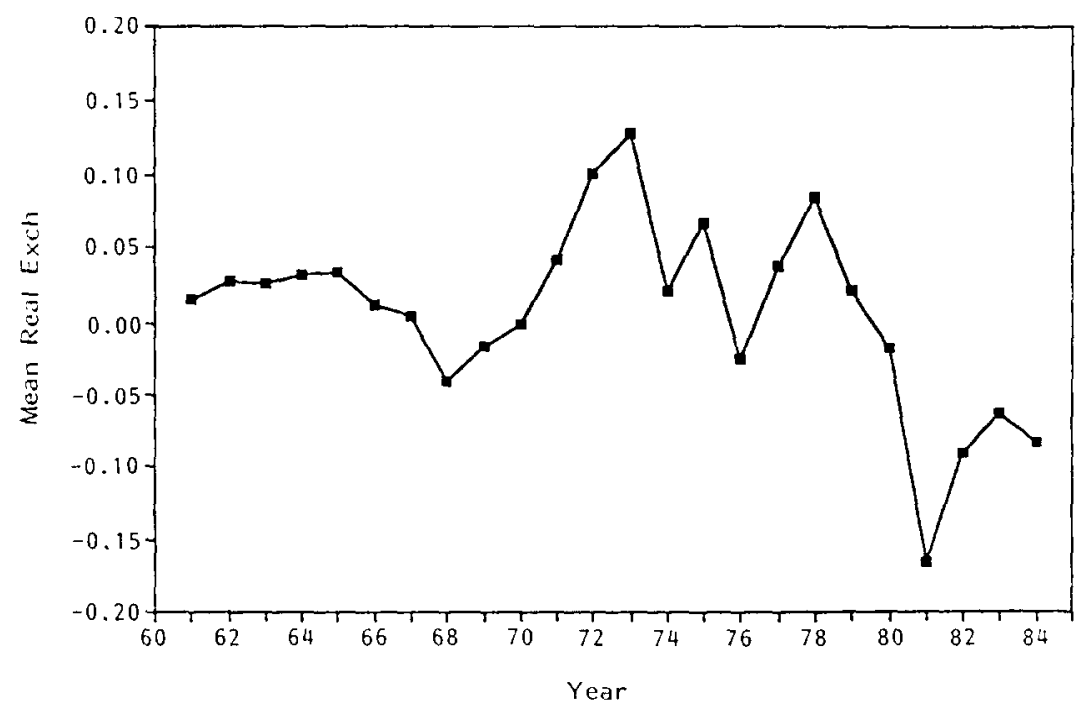

Figure 5. Cross country mean of the annual change in the real exchange rates $1961-84$.

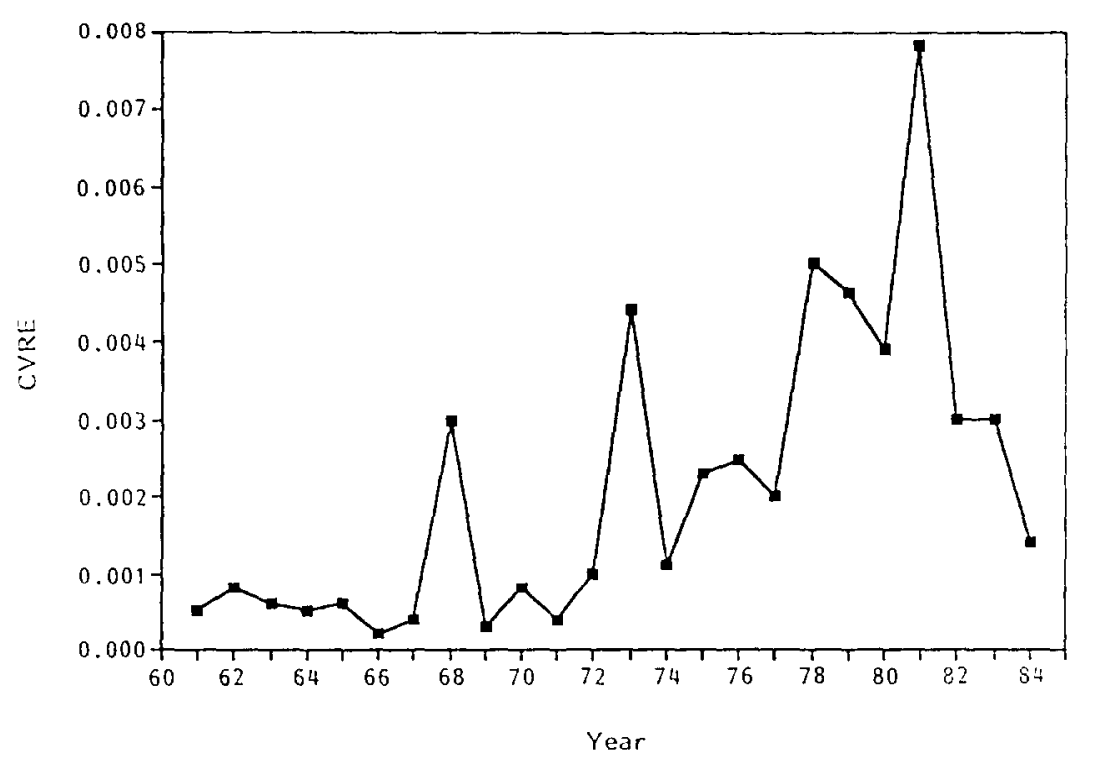

FIGURE 6. Cross-country variance of the annual change in the real exchange rates $1961-84$.

basket of consumption goods measured in terms of the basket of consumption goods in the USA (i.e., the local CPI divided by the product of the US CPI and the nominal exchange rate). These figures reveal that nominal and real exchange rates behave in a very similar fashion: both became much more volatile after the switch to a flexible exchange rate regime. This higher volatility manifests itself in the form of much higher and less stationary variances, as well as more erratic means of the exchange rates. 
In summary, an unexpected decline in the divergence of national output growth is observed in spite of many large economic shocks (e.g., two oil shocks during the last 15 years). Coincident with this observation is an increase in the volatility of both the nominal and the real exchange rate following the change to a flexible exchange rate regime. This preliminary evidence suggests that the increase in exchange rate flexibility has not led to less coherent output growth among the industrialized nations. ${ }^{6}$

Statistics from the individual countries' time series are also examined. The sample period is divided into three sub-periods: 1961-72, 1973-77, and 1978-84. Although its exact timing is not clear-cut, the first break of the sample period is necessary because of the change from a fixed to a flexible exchange rate regime. The necessity of the second break is due to strong evidence of a further regime change. When the flexible exchange rate period is split into two sub-periods (in various ways) and tested for stability, the Chow test statistics based on subsequent regression analyses were consistently well above the 5 per cent significance level and were above the 1 per cent level in most cases. Similarly, when the possibility of regime changes is ignored, the regression results reported later proved highly unstable. 8

TABLE 1. Variance of the annual real GDP growth rate.

\begin{tabular}{lcccccc}
\hline Country & & & & $1973-77 /$ & $1978-84 /$ & $1973-77 /$ \\
& $1961-72$ & $1973-77$ & $1978-84$ & $1961-72$ & $1961-72$ & $1978-84$ \\
\hline Canada & 0.0003 & 0.0007 & 0.0009 & 2.3333 & 3.0000 & 0.7778 \\
Australia & 0.0006 & 0.0003 & 0.0006 & 0.5000 & 1.0000 & 0.5000 \\
Japan & 0.0012 & 0.0012 & 0.0001 & 1.0000 & $0.0833^{*}$ & $12.0000^{*}$ \\
Austria & 0.0002 & 0.0005 & 0.0003 & 2.5000 & 1.5000 & 1.6667 \\
Belgium & 0.0003 & 0.0009 & 0.0003 & 3.0000 & 1.0000 & 3.0000 \\
Denmark & 0.0005 & 0.0011 & 0.0003 & 2.2000 & 0.6000 & 3.6667 \\
Finland & 0.0007 & 0.0007 & 0.0004 & 1.0000 & 0.5714 & 1.7500 \\
France & 0.0001 & 0.0004 & 0.0002 & $4.0000^{*}$ & 2.0000 & 2.0000 \\
Germany & 0.0004 & 0.0009 & 0.0003 & 2.2500 & 0.7500 & 3.0000 \\
Ireland & 0.0004 & 0.0008 & 0.0006 & 2.0000 & 1.5000 & 1.3333 \\
Italy & 0.0004 & 0.0018 & 0.0005 & $4.5000^{*}$ & 1.2500 & 3.6000 \\
Netherlands & 0.0003 & 0.0013 & 0.0002 & $4.3333^{*}$ & 0.6667 & $6.5000^{*}$ \\
Norway & 0.0003 & 0.0002 & 0.0004 & 0.6667 & 1.3333 & 0.5000 \\
Spain & 0.0005 & 0.0007 & 0.0001 & 1.4000 & $0.2000^{*}$ & $7.0000^{*}$ \\
Sweden & 0.0004 & 0.0005 & 0.0002 & 1.2500 & 0.5000 & 2.5000 \\
Switzerland & 0.0003 & 0.0018 & 0.0003 & $6.0000^{*}$ & 1.0000 & $6.0000^{*}$ \\
United Kingdom & 0.0002 & 0.0014 & 0.0005 & $7.0000^{*}$ & 2.5000 & 2.8000 \\
Mean & 0.0004 & 0.0009 & 0.0004 & 2.7020 & 1.1444 & 3.4467 \\
Minimum & 0.0001 & 0.0002 & 0.0001 & & & \\
Maximum & 0.0012 & 0.0018 & 0.0009 & & & \\
Range & 0.0011 & 0.0016 & 0.0008 & & & \\
\hline & & & & & & \\
\hline
\end{tabular}

Source: IFS Yearbook 1986.

Notes: The last three columns contain $F$-statistics to test the hypothesis of homogeneity between the respective periods. An asterisk denotes significance at the 5 per cent level. 
For each sub-period and for each country, three variances are computed: variances of the annual rate of real GDP growth, variances of the annual changes in nominal exchange rates, and variances of the annual changes in real exchange rates. These statistics are reported in Tables 1,2, and 3, respectively. In each table, the first column indicates the name of the country, the second, third, and fourth columns show the sub-period variances and the fifth, sixth, and seventh columns report ratios of these volatility measures.

The variances of the annual real GDP growth rate series exhibit only very small changes over the three sub-periods (Table 1). To compare the variances for the 1961-72 period with those for the 1978-84 period, their ratios (column six) are examined. Seven of these ratios are greater, while seven are less than one. The mean of all the ratios is 1.1444. If independence and a normal distribution for the annual real GDP growth rates are arbitrarily assumed. only two ratios (Japan and Spain) are greater than the 5 per cent $F$-distribution significance level. The differences between the 1961-72 and the 1973-77 periods and also between the 1973-77 and the 1978-84 periods are somewhat larger. The means of the ratios formed by these two pairs of variances (columns five and seven) are 2.7020 and 3.4467, respectively; both, however, are comfortably below the 5 per cent $F$-distribution significance level. The proportions of the individual ratios that are greater than the 5 per cent

TABLE 2. Variance of the annual change in the nominal exchange rate.

\begin{tabular}{|c|c|c|c|c|c|c|}
\hline Country & $1961-72$ & $1973-77$ & $1978-84$ & $\begin{array}{l}1973-77 / \\
1961-72\end{array}$ & $\begin{array}{l}1978-84 \\
1961-72\end{array}$ & $\begin{array}{l}1973-77 \\
1978-84\end{array}$ \\
\hline Canada & 0.0007 & 0.0020 & 0.0007 & 2.8571 & 1.0010 & 2.8571 \\
\hline Australia & 0.0002 & 0.0131 & 0.0041 & $65.5000^{*}$ & $20.5000^{*}$ & 3.1951 \\
\hline Japan & 0.0017 & 0.0061 & 0.0130 & $3.5882^{*}$ & $7.6471^{*}$ & 0.4692 \\
\hline Austria & 0.0006 & 0.0049 & 0.0136 & $8.1667^{*}$ & $22.6667^{*}$ & 0.3603 \\
\hline Belgium & 0.0009 & 0.0044 & 0.0195 & $4.8889^{*}$ & $21.6667^{*}$ & 0.2256 \\
\hline Denmark & 0.0009 & 0.0053 & 0.0125 & $5.8889^{*}$ & $13.8889^{*}$ & 0.4240 \\
\hline Finland & 0.0035 & 0.0029 & 0.0071 & 0.8286 & 2.0286 & 0.4085 \\
\hline France & 0.0014 & 0.0118 & 0.0172 & $8.4286^{*}$ & $12.2857^{*}$ & 0.6860 \\
\hline Germany & 0.0011 & 0.0054 & 0.0151 & $4.9091^{*}$ & $13.7273^{*}$ & 0.3576 \\
\hline Ireland & 0.0018 & 0.0060 & 0.0154 & $3.3333^{*}$ & $8.5556^{*}$ & 0.3896 \\
\hline Italy & 0.0003 & 0.0100 & 0.0134 & $33.3333^{*}$ & $44.6667^{*}$ & 0.7463 \\
\hline Netherlands & 0.0007 & 0.0044 & 0.0143 & $6.2857^{*}$ & $20.4286^{*}$ & 0.3077 \\
\hline Norway & 0.0004 & 0.0040 & 0.0066 & $10.0000^{*}$ & $16.5000^{*}$ & 0.6061 \\
\hline Spain & 0.0020 & 0.0109 & 0.0200 & $5.4500^{*}$ & $10.0000^{*}$ & 0.5450 \\
\hline Sweden & 0.0004 & 0.0037 & 0.0123 & $9.2500^{*}$ & 30.7500 & 0.3008 \\
\hline Switzerland & 0.0007 & 0.0048 & 0.0222 & $6.8571^{*}$ & $30.7143^{*}$ & 0.2162 \\
\hline United Kingdom & 0.0018 & 0.0060 & 0.0158 & $3.3333^{*}$ & $8.7778^{*}$ & 0.3797 \\
\hline Mean & 0.0011 & 0.0062 & 0.0131 & 10.7588 & 16.8708 & 0.7338 \\
\hline Minimum & 0.0002 & 0.0020 & 0.0007 & & & \\
\hline Maximum & 0.0035 & 0.0131 & 0.0200 & & & \\
\hline Range & 0.0033 & 0.0111 & 0.0193 & & & \\
\hline
\end{tabular}

Source: IFS Yearbook (1986) and OECD Economic Oullook (1987).

Note: See Table 1. 
TABLE 3. Variance of the annual change in the real exchange rate.

\begin{tabular}{lcccccc}
\hline Country & & & & $1973-77 /$ & $1978-84 /$ & $1973-77 /$ \\
\hline Canada & $1961-72$ & $1973-77$ & $1978-84$ & $1961-72$ & $1961-72$ & $1978-84$ \\
Australia & 0.0006 & 0.0017 & 0.0012 & 2.8333 & 2.0000 & 1.4167 \\
Japan & 0.0008 & 0.0101 & 0.0013 & $12.6250^{*}$ & 1.6250 & $7.7692^{*}$ \\
Austria & 0.0017 & 0.0038 & 0.0145 & 2.2353 & $8.5294^{*}$ & 0.2621 \\
Belgium & 0.0012 & 0.0052 & 0.0104 & $4.3333^{*}$ & $8.667^{*}$ & 0.5000 \\
Denmark & 0.0015 & 0.0034 & 0.0142 & 2.2667 & $9.4667^{*}$ & 0.2394 \\
Finland & 0.0013 & 0.0048 & 0.0114 & $3.6923^{*}$ & $8.7692^{*}$ & 0.4211 \\
France & 0.0037 & 0.0022 & 0.0033 & 0.5946 & 0.8919 & 0.6667 \\
Germany & 0.0022 & 0.0103 & 0.0128 & $4.6828^{*}$ & $5.8182^{*}$ & 0.8047 \\
Ireland & 0.0015 & 0.0075 & 0.0125 & $5.0000^{*}$ & $8.3333^{*}$ & 0.6000 \\
Italy & 0.0029 & 0.0034 & 0.0085 & 1.1724 & 2.9310 & 0.4000 \\
Netherlands & 0.0012 & 0.0071 & 0.0105 & $5.9167^{*}$ & $8.7500^{*}$ & 0.6762 \\
Norway & 0.0015 & 0.0041 & 0.0121 & 2.7333 & $8.0667^{*}$ & 0.3388 \\
Spain & 0.0011 & 0.0036 & 0.0024 & 3.2727 & 2.1818 & 1.5000 \\
Sweden & 0.0044 & 0.0058 & 0.0202 & 1.3182 & $4.5909^{*}$ & 0.2871 \\
Switzerland & 0.0010 & 0.0025 & 0.0085 & 2.5000 & $8.5000^{*}$ & 0.2941 \\
United Kingdom & 0.0017 & 0.0091 & 0.0185 & $5.3529^{*}$ & $10.8824^{*}$ & 0.4919 \\
Mean & 0.0027 & 0.0056 & 0.0172 & 2.0741 & $6.3704^{*}$ & 0.3256 \\
Minimum & 0.0018 & 0.0053 & 0.0106 & 3.6825 & 6.2573 & 0.9996 \\
Maximum & 0.0006 & 0.0017 & 0.0012 & & & \\
Range & 0.0044 & 0.0103 & 0.0202 & & & \\
\hline Sorce & 0.0038 & 0.0086 & 0.0190 & & & \\
\hline
\end{tabular}

Source: IFS rearbook (1986) and OECD Econtomic Outlook (1987).

Note: See Table 1.

$F$-distribution significance level are only 0.294 and 0.235 , respectively. Finally, the ranges of the distribution of the variances in the three periods are not very different. These results suggest that volatility in output growth for individual countries has not changed much in our sample period.

The nominal and the real exchange rate series, in contrast to the output growth series, become much more volatile after the 1961-72 period (Tables 2 and 3). Indeed, the change is quite dramatic. The variances of both exchange rate changes in the second and the third periods are on average six times greater than their counterparts in the first period. All of the ratios of the variances for the last two periods compared to those for the first period are greater than one except those of Finland. In the case of the nominal exchange rate, more than 88 per cent of the ratios are greater than the 5 per cent $F$-distribution significance level. In the case of the real exchange rate, 41 per cent of the individual ratios of the variances for the second period compared to those for the first period are greater than the 5 per cent $F$-distribution significance level, while 71 per cent of the ratios formed by the variances for the first and the third periods are significant. The ranges of the variances in the last two periods are about three times larger than those in the first period. ${ }^{9}$ These results indicate that both nominal exchange rates and real exchange rates became considerably more volatile during the flexible rate period. Similar, 
but much more extensive evidence of this phenomenon is documented in Mussa (1986).

The above results indicate that after the switch from a fixed to a flexible exchange rate regime, output growth actually became less dispersed across countries, while volatility of output growth within individual countries did not increase to any great extent. These observations are curious because they took place in the context of the often alleged increase in economic turbulence after the 1960 s, the increase in monetary policy independence documented in Darby and Lothian (1989), and much more volatile exchange rate behavior. The natural question to ask is whether exchange rate variability has a significant statistical relationship with individual country output volatility and with cross-country divergences in output growth.

The results also suggest that price flexibility does not destabilize output growth. This inference is based on the fact that real exchange rates are relative prices of national output and on the belief that exchange rate volatility is a proxy for the degree of price flexibility, a point which will be discussed later.

\section{Regression results}

To answer the above questions, the regression technique is used to further examine the data. Three specific hypotheses are examined:

1. Flexibility in exchange rates has a negative relationship with dispersion in output growth across countries.

2. Flexibility in exchange rates has a negative relationship with volatility in output growth within countries.

3. Flexibility in price has a positive relationship with output stability.

\section{III.A. Exchange rate flexibility and cross-country dispersion in output growth}

A first pass examination of the hypothesis that flexibility in exchange rates is associated with less dispersion in output growth across countries is conducted by running the following regression equations: ${ }^{10}$

$$
\begin{aligned}
& \mathrm{CVG}=a+b * \mathrm{CVNE} \\
& \mathrm{CVG}=a+b * \mathrm{CVRE}
\end{aligned}
$$

where CVG is the cross-country variance of the annual growth in real GDP, CVNE and CVRE are the cross-country variances of the annual changes in the nominal and the real exchange rate, respectively. CVG is indicative of the degree of divergence of output performance among the economies, while CVNE and CVRE are indices for the degree of flexibility in exchange rates.

The results of these regressions, which are reported in Table 4, support the hypothesis that flexibility in exchange rates is associated with more coherent output growth among the industrialized nations. In both the case of the nominal and the real exchange rate, the estimated slope coefficients are negative and rather significant (a low prob-value). This is particularly so for the real exchange rates. ${ }^{11}$

To provide further evidence of the relationship between flexibility of exchange rates and coherence of output growth across countries, each individual country's real GDP growth is decomposed linearly into a global component and a country-specific residue as follows: 
TABLE 4. Regression result--equations $\langle 1\rangle$ and $\langle 2\rangle$.

Dependent variable: Cross-country variance of the annual real GDP growth (CVG)

Independent variable: Cross-country variance of the annual change in the nominal exchange rate (CVNE)

\begin{tabular}{|c|c|c|c|c|c|}
\hline Period & Variable & $\begin{array}{l}\text { Parameter } \\
\text { estimate }\end{array}$ & $\begin{array}{l}\text { Standard } \\
\text { error }\end{array}$ & $\begin{array}{c}T \text { for } H o \\
(\text { Parameter }=0)\end{array}$ & Prob $>\mid T$ \\
\hline $1961-84$ & $\begin{array}{l}\text { Constant } \\
\text { CVNE }\end{array}$ & $\begin{array}{r}0.00058 \\
-0.03367\end{array}$ & $\begin{array}{l}0.00006 \\
0.01653\end{array}$ & $\begin{array}{r}9.290 \\
-2.037\end{array}$ & $\begin{array}{l}0.0001 \\
0.054\end{array}$ \\
\hline
\end{tabular}

$F=4.148 \quad$ Prob $>F=0.054$

Degrees of freedom: 22 Adjusted $R$-square: 0.1204

Independent variable: Cross-country variance of the annual change in the real exchange rate (CVRE)

\begin{tabular}{llcccc} 
Period & Variable & $\begin{array}{c}\text { Parameter } \\
\text { estimate }\end{array}$ & $\begin{array}{c}\text { Standard } \\
\text { error }\end{array}$ & $\begin{array}{c}T \text { for } \mathrm{Ho} \\
\text { (Parameter }=0)\end{array}$ & Prob $>|T|$ \\
\hline $1961-84$ & Constant & 0.00062 & 0.00007 & -9.408 & 0.0001 \\
& CVRE & -0.05737 & 0.02318 & -2.475 & 0.0215
\end{tabular}

$F=6.126 \quad$ Prob $>F=0.0215$

Degrees of freedom: 22 Adjusted $R$-square: 0.1822

$$
g y_{i t}=a_{i}+b_{i} * w g_{t}+e_{i t}
$$

where $g y$ is real GDP growth, $w g$ is aggregate real output growth of the industrialized countries, ${ }^{12} e$ is the country specific residue in output growth, and $i$ and $t$ are country and time subscripts, respectively. In estimation, the parameters $a_{i}$ and $b_{i}$ are allowed to vary across the three sub-periods, namely 1961-72, 1973-77, and 1978-84.

If flexibility in exchange rates does lead to more coherent output performance internationally, then the parameter estimates should be less dispersed across the nations during the flexible exchange rate sub-periods. This is indeed the case. The cross-country variance of $a_{i}$ decreases from 0.0007 for the first (fixed exchange rate) period to 0.00027 for the second period and to 0.00017 for the third period (the second and third periods are both in the flexible exchange rate regime). The cross-country variance of $b_{i}$ decreases from 0.43608 for the first period to 0.21521 for the second period and to 0.14904 for the third period. Similarly, the cross-country variance of the estimated variances of $e_{i t}$ drops from $10^{-8} \times 8$ for the first period to $10^{-8} \times 2$ for the third period, although it rises to $10^{-8} \times 9$ for the second period. All dispersion estimates decrease by at least three times from the first period to the last period. These sharp decreases add to the evidence that industrialized countries' output growth is much more coherent after the switch from a fixed to a flexible exchange rate system. ${ }^{13}$

The question remains whether the simultaneous increase in the coherence of output growth and in exchange rate flexibility (due to the switch to a flexible exchange rate system) is merely a spurious coincidence. To shed light on this issue, 
the relationship between the parameter estimates $\left(a_{i}, b_{i}\right.$, and $\left.\operatorname{var}\left(e_{i t}\right)\right)$ and the volatility of the corresponding country's exchange rates is examined. If the increase in exchange rate flexibility is indeed more than spuriously related to the decrease in dispersion in output growth, then the volatility of a country's exchange rate changes should be negatively correlated with the deviations from the cross-country mean of the parameter estimates, especially in the flexible rate period.

For each of the three sub-periods, three vectors of the squared deviations of the $a_{i}, b_{i}$, and $\operatorname{var}\left(e_{i t}\right)$ are obtained from their corresponding cross-country mean: SDA, SDB, and SDVE, respectively. Also, for each country and for each sub-period, the variances of the nominal and real exchange rate changes are obtained. These vectors are called VNE and VRE, respectively. Finally, the three sets of vectors are stacked and the following regressions are run using the SUR technique:

$$
\begin{aligned}
& S_{1}=c+d * \mathrm{VNE}, \\
& S_{1}=c+d * \mathrm{VRE},
\end{aligned}
$$

where $S_{1}=\mathrm{SDA}, \mathrm{SDB}$, and SDVE, respectively.

The results are reported in Table 5 . The regression is most successful in the case of SDB: The estimate for $d$ is negative in all instances except in the regression on VRE for the second period, and the estimate is significant (with a prob-value of about 2 per cent ) in the 1978-84 period. ${ }^{14}$ The estimate for $d$ is generally negative in the case of SDA while the opposite is true for SDVE. However, $d$ is not significant in either case.

The respective coefficients of correlation between SDA, SDB, and SDVE and the exchange rate volatility measures are also reported. These correlation coefficients are all negative when the data are pooled for the three sub-periods and are significant in the case of both SDB and SDA. The correlation coefficients for the individual sub-periods are generally negative for SDB and SDA. Not surprisingly, they are significant for the last period in the case of SDB. SDA is also significantly negatively correlated with VNE for the last period. The sub-period estimates for SDVE are all positive but insignificant.

The results suggest that the deviations from the cross-country mean of $a_{i}$ and $b_{i}$ are negatively related to country $i$ 's exchange rate volatility. The relationship becomes much stronger in the case of the $h_{i} \mathrm{~s}$ after the industrialized economies have adopted a flexible exchange rate system for a few years. ${ }^{15}$ The conclusion is that the decrease in divergence in output growth across countries after the exchange rate regime change is not simply spuriously related to the increase in exchange rate flexibility.

\section{III.B. Exchange rate flexibility and output volatility}

The second hypothesis examined is that flexibility in exchange rates is negatively correlated with output volatility within countries. To do so, the variances of the individual country output growth series are regressed on the corresponding variances of both the real and nominal exchange rate change series as follows:

$$
\begin{aligned}
& \mathrm{VG}=h+k * \mathrm{VNE}, \\
& \mathrm{VG}=h+k * \mathrm{VRE},
\end{aligned}
$$


TABLE 5. Regression result-equations $\langle 4\rangle$ and $\langle 5\rangle$.

\begin{tabular}{|c|c|c|c|c|c|c|c|}
\hline \multirow{2}{*}{$\begin{array}{l}\text { Dependent } \\
\text { variable: }\end{array}$} & & \multicolumn{2}{|c|}{ SDA } & \multicolumn{2}{|c|}{ SDB } & \multicolumn{2}{|c|}{ SDVE } \\
\hline & & (SUR) & (CORR) & (SUR) & (CORR) & (SUR) & (CORR) \\
\hline \multirow[t]{3}{*}{$1961-72$} & $\mathrm{C}$ & 0.00095 & & 0.42422 & & 0.00561 & \\
\hline & VNE & -0.26327 & -0.305 & -12.1790 & -0.031 & 41.4887 & 0.413 \\
\hline & & $(-1.14)$ & $(1.24)$ & $(-0.091)$ & $(0.12)$ & (1.673) & $(1.76) !$ \\
\hline \multirow[t]{4}{*}{$1973-77$} & C & 0.00039 & & 0.31709 & & 0.07045 & \\
\hline & & $(2.535)^{*}$ & & $(2.274)^{*}$ & & $(1.896) !$ & \\
\hline & VNE & -0.02219 & -0.137 & -18.4350 & -0.206 & 2.80241 & 0.149 \\
\hline & & $(-1.02)$ & $(0.54)$ & $(-0.92)$ & $(0.82)$ & $(0.539)$ & $(0.58)$ \\
\hline \multirow[t]{4}{*}{$1978-84$} & $\mathrm{C}$ & 0.00036 & & 0.36786 & & 0.00773 & \\
\hline & & $(2.546)^{*}$ & & $(3.799)^{*}$ & & $(0.763)$ & \\
\hline & VNE & -0.01538 & -0.426 & -17.3620 & -0.567 & 0.95815 & 0.235 \\
\hline & & $(-1.57)$ & $(1.82)^{*}$ & $(-2.55)^{*}$ & $(2.67)^{*}$ & $(1.368)$ & $(0.94)$ \\
\hline \multirow[t]{2}{*}{$1961-84$} & VNE & & -0.376 & & -0.386 & & 0.096 \\
\hline & & & $(2.84)^{*}$ & & $(2.95)=$ & & $(0.68)$ \\
\hline D F & & 45 & & 45 & & 45 & \\
\hline \multicolumn{2}{|l|}{$\%$ Explained: } & 10.1 & & 14.2 & & 9.34 & \\
\hline \multirow[t]{4}{*}{$1961-72$} & $\mathrm{C}$ & 0.00123 & & 0.56167 & & 0.05480 & \\
\hline & & $(3.257)^{*}$ & & $(2.537)^{*}$ & & $(1.138)$ & \\
\hline & VRE & -0.31321 & -0.407 & -82.8946 & -0.186 & -1.22075 & 0.101 \\
\hline & & $(-1.74) !$ & $(1.73) !$ & $(-0.78)$ & $(0.73)$ & $(-0.05)$ & $(0.39)$ \\
\hline \multirow[t]{4}{*}{$1973-77$} & C & 0.00023 & & 0.08906 & & 0.05247 & \\
\hline & & $(1.434)$ & & $(0.622)$ & & $(1.392)$ & \\
\hline & VRE & 0.00420 & 0.157 & 21.3649 & 0.221 & 6.66270 & 0.162 \\
\hline & & $(0.158)$ & $(0.62)$ & $(0.883)$ & $(0.88)$ & $(1.074)$ & $(0.64)$ \\
\hline \multirow[t]{4}{*}{$1978-84$} & $\mathrm{C}$ & 0.00025 & & 0.32386 & & 0.00902 & \\
\hline & & $(1.998) !$ & & $(3.910)^{*}$ & & $(1.120)$ & \\
\hline & VRE & -0.00919 & -0.257 & -17.3773 & -0.507 & 1.06634 & 0.264 \\
\hline & & $(-0.87)$ & (1.03) & $(-2.524)^{*}$ & $(2.28)^{*}$ & $(1.644)$ & $(1.06)$ \\
\hline \multirow[t]{2}{*}{$1961-84$} & VRE & & -0.316 & & -0.319 & & -0.900 \\
\hline & & & $(2.33)^{*}$ & & $(2.35)^{*}$ & & $(0.63)$ \\
\hline \multirow{2}{*}{\multicolumn{2}{|c|}{$\begin{array}{l}\text { D F: } \\
\% \text { Explained: }\end{array}$}} & 45 & & 45 & & 45 & \\
\hline & & 7.9 & & 14.2 & & 7.5 & \\
\hline
\end{tabular}

The numbers in parentheses are $t$-values.

\#, ", and ! represent significance at the 1 per cent, 5 per cent, and 10 per cent levels, respectively.

where VG is the variance of a country's annual GDP growth series, VNE and VRE are, as above, the variance of the corresponding country's series of nominal and real exchange rate changes, respectively. There are again three sets of vectors of variances: those obtained for the 1961-72 period, the 1973-77 period, and the 1978-84 period. The three sets of vectors are stacked and the SUR regression technique is applied.

The results are reported in Table $6 .{ }^{16}$ The variances of both the nominal and real exchange rate changes are most capable of explaining the variance of real output changes for the 1978-84 period. Their regression coefficients are negative and highly significant with a prob-value much smaller than 0.1 per cent. The evidence 
TABLE 6. Regression result--equations $\langle 6\rangle$ and $\langle 7\rangle$.

Dependent variable: Variance of the annual real GDP growth (VG)

Independent variable: Variance of the annual change in the nominal exchange rate (VNE)

\begin{tabular}{llcccc} 
Period & Variable & $\begin{array}{c}\text { Parameter } \\
\text { estimate }\end{array}$ & $\begin{array}{c}\text { Standard } \\
\text { error }\end{array}$ & $\begin{array}{c}T \text { for } \text { Ho } \\
\text { (Parameter }=0)\end{array}$ & Prob $>|T|$ \\
\hline $1961-72$ & Constant & 0.00309 & 0.00009 & 3.361 & 0.0043 \\
& VNE & 0.09685 & 0.06278 & 1.543 & 0.1438 \\
$1973-77$ & Constant & 0.00102 & 0.00025 & 4.408 & 0.0011 \\
& VNE & -0.01888 & 0.03549 & -0.532 & 0.6026 \\
$1978-84$ & Constant & 0.00077 & 0.00088 & 8.756 & 0.0001 \\
& VNE & -0.03108 & 0.00600 & -5.180 & 0.0001
\end{tabular}

Degrees of freedom: 45

$\%$ Variation explained: 39.71

Independent variable: Variance of the annual change in the real exchange rate (VRE)

\begin{tabular}{llrrrr} 
Period & Variable & $\begin{array}{l}\text { Parameter } \\
\text { estimate }\end{array}$ & $\begin{array}{l}\text { Standard } \\
\text { error }\end{array}$ & $\begin{array}{l}T \text { for } H \text { (o) } \\
\text { (Parameter }=0)\end{array}$ & Prob $>|T|$ \\
\hline $1961-72$ & Constant & 0.00035 & 0.00012 & 2.850 & 0.0122 \\
& VRE & 0.03934 & 0.05715 & 0.688 & 0.5018 \\
$1973-77$ & Constant & 0.00080 & 0.00025 & 3.168 & 0.0064 \\
& VRE & 0.01887 & 0.04188 & 0.451 & 0.6587 \\
$1978-84$ & Constant & 0.00068 & 0.00008 & 8.837 & 0.0001 \\
& VRE & -0.02959 & 0.00619 & -4.779 & 0.0002
\end{tabular}

Degrees of freedom: 45

$\%$ Variations explained: 35.47

clearly indicates that, after the world is adjusted to a flexible exchange rate regime, flexibility in exchange rates is associated with less output volatility. ${ }^{17}$

The regression coefficients are unstable for the 1973-77 period, the period in which the flexible exchange rate system was being implemented. This result is not surprising. The world economy was undergoing adjustment to the new flexible exchange rate regime during the 1973-77 period: therefore statistical stationarity is likely absent. In such circumstances, we cannot expect to obtain reliable regression estimates. A statistical analysis lumping the 1973-77 period together with either of the other periods, as if the two belonged to a uniform regime, would generate unreliable results.

The regression coefficients are positive for the first period in both the nominal and the real exchange rate cases. The prob-value in the nominal exchange rate case is 0.144 . The coefficient in the real exchange rate case is not significant. The positive relationship between the variance of exchange rate changes and the variance of output growth during the 1961-72 fixed exchange rate period is interpreted as evidence that a government changes its pegged exchange rate more often the more volatile is output growth. The alternative explanation of the regression estimates, 
that exchange rate flexibility causes output volatility, is inconsistent with the results obtained for the 1978-84 period and the fact that output volatility is not higher during the 1961-72 period.

Also examined is the relationship between exchange rate volatility and two components in the variance of output growth. As in equation $\langle 3\rangle$ the variance of individual country output growth is decomposed into a global and a country-specific component. In the notation of equation $\langle 3\rangle$, the global component for a country, $i$, is $b_{i}^{2} * \operatorname{var}\left(w g_{t}\right)$, where $w g_{t}$ is aggregate real output growth of the industrialized countries in year $t$. It represents the fluctuations in the part of country i's output growth that is influenced by global output growth. The country-specific component is var $\left(e_{i t}\right)$. It represents the fluctuations in the part of country is output growth that is uncorrelated with the global economy. Knowledge of how exchange rate volatility is related to each of the two components is desired. This information sheds light on why exchange rate volatility is negatively correlated with output volatility.

For each sub-period (1961-72, 1973-77, and 1978-84), four vectors are obtained: $b_{i} s, \operatorname{var}\left(e_{i t}\right),{ }^{18}$ variances of nominal exchange rate changes (VNE). and variances of real exchange rate changes (VRE). The vectors are stacked by period and the following regressions are run using the SUR technique: ${ }^{19}$

$$
\begin{aligned}
\operatorname{var}\left(e_{i t}\right) & =n+m * \mathrm{VNE}, \\
\operatorname{var}\left(e_{i t}\right) & =n+m * \mathrm{VRE}, \\
b_{i}^{2} & =n+m * \mathrm{VNE}, \\
b_{i}^{2} & =n+m * \mathrm{VRE} .
\end{aligned}
$$

The results are reported in Table 7 . The variances of both the nominal and real exchange rate changes are again most capable of explaining $\operatorname{var}\left(e_{i t}\right)$ and $b_{i}^{2}$ in the 1978-84 period: the slope coefficient, $m$, is negative and highly significant except in the case of equation $\langle 8\rangle$. The estimates for $m$ are not significant for the 1961-72 and 1973-77 periods. This result is not different from that obtained for equations $\langle 6\rangle$ and $\langle 7\rangle$ (Table 6).

The results suggest that the negative relation between exchange rate flexibility and volatility in output growth observed in the 1978-84 period is due to two effects. First, flexibility in exchange rates is associated with less volatility in country-specific shocks to output growth. Second, nexibility in exchange rates is also associated with a lower impact of global fluctuations on domestic output growth. Perhaps the second effect explains why output volatility at the individual country level in the 1978-84 period was not higher than in the 1961-72 period even though the global environment was more volatile in the $1978-84$ periods. ${ }^{20}$ The evidence suggests that flexible exchange rates indeed have an insulation effect.

\section{III.C. Price flexibility and output stability}

The final hypothesis of interest is that flexibility in prices does not destabilize output growth. The hypothesis is supported by the following empirical results.

Concentration is first placed on the results pertaining to the real exchange rate which, by definition, is the real price of national output. Support for this hypothesis is provided by the descriptive statistics presented earlier in Section II. These 
TABLE 7. Regression result-equations $\langle 8\rangle$ to $\langle 11\rangle$.

\begin{tabular}{|c|c|c|c|c|c|}
\hline $\begin{array}{l}\text { Equation: } \\
\text { Variable: }\end{array}$ & & $\begin{array}{c}8 \\
\operatorname{var}\left(e_{i t}\right)\end{array}$ & $\begin{array}{c}9 \\
\operatorname{var}\left(e_{i t}\right)\end{array}$ & $\begin{array}{l}10 \\
b_{i}^{2}\end{array}$ & 11 \\
\hline \multirow[t]{2}{*}{$1961-72$} & VNE & $\begin{array}{c}0.00028= \\
(3.2026)^{\mathrm{a}} \\
(0.0059)^{\mathrm{b}} \\
0.09367 \\
(1.5489) \\
(0.1422)\end{array}$ & $\begin{array}{l}0.00033^{*} \\
(2.8503) \\
(0.0122)\end{array}$ & $\begin{array}{c}0.37209 \\
(1.3780) \\
(0.1884) \\
79.2547 \\
(0.4194) \\
(0.6809)\end{array}$ & $\begin{array}{l}0.48397 \\
(1.4928) \\
(0.1562)\end{array}$ \\
\hline & VRE & & $\begin{array}{r}0.03295 \\
(0.6104) \\
(0.5507)\end{array}$ & & $\begin{array}{c}-12.1515 \\
(-0.079) \\
(0.9378)\end{array}$ \\
\hline \multirow[t]{2}{*}{$1973-77$} & VNE & $\begin{array}{c}0.00059= \\
(3.9022) \\
(0.0014) \\
-0.00970 \\
(-0.458) \\
(0.6535)\end{array}$ & $\begin{array}{l}0.00077= \\
(5.4873) \\
(0.0001)\end{array}$ & $\begin{array}{c}0.46043 ! \\
(1.9886) \\
(0.0653) \\
6.78911 \\
(0.2071) \\
(0.8387)\end{array}$ & $\begin{array}{c}0.35878 \\
(1.5255) \\
(0.1479)\end{array}$ \\
\hline & VRE & & $\begin{array}{c}-0.04484 ! \\
(-1.955) \\
(0.0695)\end{array}$ & & $\begin{array}{l}27.0755 \\
(0.6909) \\
(0.5002)\end{array}$ \\
\hline \multirow[t]{2}{*}{$1978-84$} & VNE & $\begin{array}{c}0.00040= \\
(4.7782) \\
(0.0002) \\
0.00848 \\
(-1.488) \\
(0.1575)\end{array}$ & $\begin{array}{l}0.00041= \\
(6.2335) \\
(0.0001)\end{array}$ & $\begin{array}{c}1.13854= \\
(5.3342) \\
(0.0001) \\
-58.7089= \\
(-3.917) \\
(0.0014)\end{array}$ & $\begin{array}{l}0.92545= \\
(4.7188) \\
(0.0003)\end{array}$ \\
\hline & VRE & & $\begin{array}{c}-0.01196^{*} \\
(-2.256) \\
(0.0394)\end{array}$ & & $\begin{array}{c}-52.6727= \\
(-3.242) \\
(0.0055)\end{array}$ \\
\hline $\begin{array}{l}\text { D F: } \\
\% \text { Explained: }\end{array}$ & & $\begin{array}{l}45 \\
9.22\end{array}$ & $\begin{array}{l}45 \\
15.01\end{array}$ & $\begin{array}{l}45 \\
25.75\end{array}$ & $\begin{array}{l}45 \\
20.07\end{array}$ \\
\hline
\end{tabular}

$a=t$-value ${ }^{b}=$ prob-value $>|t|$.

$\because{ }^{*}$, and ! represent significance at the 1 per cent. 5 per cent, and 10 per cent levels, respectively.

statistics indicated that the increase in the flexibility of the real price, caused by a change in exchange rate regime in the early 1970s, coincided with no increase in output volatility in spite of the existence of substantial economic shocks, such as the series of energy crises. The regression estimates presented in this section provide further support for the hypothesis. The regression coefficient, $k$, in equation $\langle 7\rangle$ was negative and significant in the 1978-84 period: the volatility of real exchange rate changes-a proxy for the flexibility of the real price of national output-was negatively correlated with the volatility of output itself. Moreover, the regression coefficient, $m$, in equation $\langle 9\rangle$ was also negative and significant, indicating that the volatility of the real exchange rate changes was negatively correlated with the country-specific output volatility.

One problem with these results, however, is that in the standard discussion of the relationship between price flexibility and output stability, the price variable is 
usually the nominal price level in a closed economy. In the present context, this price should be the internal nominal price of each nation. This is different from the relative price of each nation's output. Therefore, it may be argued that the empirical results for the real exchange rate do not provide direct evidence on the issue.

It could be argued further, however, that a higher variance of the nominal exchange rate changes is indicative of a higher degree of flexibility of the internal price. The relative price and the nominal exchange rate are both algebraic components of the internal price (CPI). An increase in the flexibility of these two components, which a higher variance of the exchange rate (real and nominal) changes would suggest, could conceivably lead to a higher degree of flexibility in the internal price.

A more complicated argument in favor of a positive relationship between the variance of exchange rate changes and internal price flexibility can be based on an intuitively appealing result due to Mussa $(1981$, p. 1023, equations $\langle 8\rangle$ and $\langle 11\rangle)$. Mussa shows that the general price level is more flexible the higher the expected inflation rate. ${ }^{21}$ It would be expected then that, if an increase in the variance of the nominal exchange rate is indeed indicative of an increase in the flexibility of the internal price, the same variance is positively correlated with the mean inflation rate. This turns out to be the case. The variances of the 17 countries' series of nominal exchange rate changes are regressed on the corresponding means of the inflation rate series. There are three pairs of vectors, one for each of the three sub-periods. The vectors are stacked and the SUR regression technique is applied. The regression estimates, which are reported in Table 8 , indicate clearly that the volatility of the exchange rates is positively correlated with the mean of the inflation rates. ${ }^{22}$ Based on these regression estimates, it is believed that a higher variance in exchange rate changes is indeed associated with an increase in price level flexibility.

To explore further whether the variance of the exchange rate changes is indicative of the degree of internal price flexibility, the correlation coefficient

TABLE 8. Cross-country regression-volatility of exchange rate changes on mean inflation.

Dependent variable: Variance of the annual change in the nominal exchange rate (VNE)

Independent variable: Mean annual inflation rate

\begin{tabular}{llrrrr} 
Period & Variable & $\begin{array}{c}\text { Parameter } \\
\text { estimate }\end{array}$ & $\begin{array}{c}\text { Standard } \\
\text { error }\end{array}$ & $\begin{array}{c}T \text { for } H o \\
\text { (Parameter }=0)\end{array}$ & Prob $>|T|$ \\
\hline $1961-72$ & Constant & -0.00042 & 0.00077 & -0.547 & 0.5921 \\
& MI & 0.03428 & 0.01660 & 2.065 & 0.0566 \\
$1973-77$ & Constant & 0.00133 & 0.00235 & 0.566 & 0.5799 \\
& MI & 0.04317 & 0.01971 & 2.190 & 0.0447 \\
$1978-84$ & Constant & 0.00498 & 0.00307 & 0.623 & 0.1254 \\
& MI & 0.05857 & 0.03201 & 1.830 & 0.0827
\end{tabular}

Degrees of freedom: 45

$\%$ Variations explained: 22.39 
between the vectors of variances of nominal exchange rate changes and the vectors of variances of inflation rates is estimated. To increase the sample size, the variances are pooled from all three sub-periods. The estimate is 0.24 . Under the assumption of independence for each pair of variances, the prob-value is $0.0893 .^{23}$ It appears that there is some validity in using the variance of exchange rate changes as a proxy for internal price flexibility. ${ }^{24}$

The above evidence is unfavorable to the following competing interpretation of the variance of exchange rate changes. An implication of the 'overshooting' argument in Dornbusch (1976) is that sluggish price adjustment in the commodity and labor markets results in increased volatility of exchange rates. A higher variance of exchange rate changes could then be associated with a lower degree of price flexibility. The results reported in Table 8 and the positive correlation between the variance of inflation and of exchange rate changes reported above indicate that a higher variance of exchange rate changes is not indicative of a more sluggish price adjustment.

In summary, the variance of the nominal exchange rate changes is an indicator of the flexibility of the internal price of national output, just as the variance of the real exchange rate is an indicator of the flexibility of the relative price of national output. The statistics reported in Section II and the regression estimates in this section (equations $\langle 6\rangle$ and $\langle 8\rangle$ ) pertaining to the case of the nominal exchange rate are qualitatively similar to those pertaining to the case of the real exchange rate. Therefore, those results provide support for the hypothesis that flexibility in the internal price is not destabilizing, just as the results obtained using the real exchange rate support the hypothesis that flexibility in the real price is not destabilizing.

\section{Conclusions}

In examining the relationship between output volatility and the volatility of exchange rates in both the flexible and the fixed exchange rate regimes, the following results are obtained: First, output growth of the industrialized countries has become more coherent since the change to a flexible exchange rate system. Second, in a flexible exchange rate system, the more flexible an exchange rate the less volatile is a country's total output growth. Exchange rate flexibility is negatively correlated with the volatility of the portion of output growth uncorrelated with global factors. It is also negatively correlated with the impact of fluctuations in global output growth on domestic output growth. These observations appear not to be spurious. On the contrary, exchange rate flexibility appears to have played a big behavioral role. These observations, thus, stand as partial, yet important, guidelines for open economy macro-model building. Finally, the results indicate that an increase in price flexibility is not destabilizing.

The reported statistical relationships suggest some important future empirical and theoretical work. For instance, it is necessary to investigate why output growth rate became more coherent across nations as exchange rate flexibility increased. What role did the exchange rate play here? Also, it is important to understand why volatility in output growth is negatively correlated with exchange rate variability in a flexible exchange rate regime. Why was exchange rate volatility negatively related to the volatility of the country-specific component of output growth? Why was exchange rate volatility negatively correlated with the impact of 
fluctuations in global output growth on domestic output growth? What are the implications of these observations on the nature of shocks in our sample period? On the shock absorbing ability and the insulation properties of a flexible exchange rate system? On the international transmission mechanism of shocks?

From the perspective of exchange rate policy management, the results must be viewed in a balanced context and considered in conjunction with other important observations. De Grauwe (1988), for instance, shows that variability in the real exchange rate in the 1973-84 flexible rate period is significantly related to the decline in export growth, although such variability is not the major explanatory variable.

Kormendi and Meguire, in their cross-country study (1985), show that mean output growth rate is positively related to the volatility of output growth and negatively related to the volatility of monetary shocks. Since variations in money supply and in exchange rates are very likely positively correlated, and since the results show that variations in output growth and exchange rate changes are negatively correlated, it is suspected that mean output growth is negatively correlated with exchange rate volatility. This is borne out by a preliminary investigation. ${ }^{25}$ Thus, there appears to be a potential trade-off between mean rates of output growth and price and monetary stability. The possibility of these trade-offs should be considered in policy-making.

\section{Notes}

1. After more than 15 years of experience with floating exchange rates, there is a growing interest in the question of empirical differences, if any, in the behavior of macro-economic variables under fixed and flexible exchange rate systems. De Grauwe (1988) reports that variability in exchange rates is negatively correlated with export growth. Darby and Lothian (1989) report that flexible exchange rates have been accompanied by greater long-run monetary policy independence. Baxter and Stockman (1989) state that they have been unable to find evidence that the cyclic behavior of real macro-economic aggregates, other than the real exchange rate, depends systematically on the exchange rate regime.

2. Driskill and Sheffrin (1986) and De Long and Summers (1986a) differ in at least two ways: (i) the demand for money curve is independent of income in the former's model but not in the latter's; (ii) the respective sets of parameter values in the simulation analyses are not identical.

3. The relationship also depends on the government's economic policies, in particular, its reaction to economic disturbances.

4. The investigation has a unique advantage. The degree of flexibility of a price system is an endogenously determined economic variable. This implies that reliable empirical evidence on the impact of an increase in price flexibility on output stability is difficult to obtain. Also, the policy content of such evidence has to be interpreted with care. Even if the relationship between price flexibility and output stability was known, it would not necessarily follow that the means to change the stability of output are available, nor would it necessarily be the case that doing so is beneficial. The policy implications of the relationship between price flexibility and output stability are, therefore, far from being straightforward. When it comes to exchange rates, the situation is somewhat different-an exchange rate regime is more a direct policy choice than is the degree of price flexibility.

5. To preserve the validity of the assumption that the relationship between exchange rate flexibility and output volatility is homogeneous across nations, it is necessary to eliminate three outliers: Iceland, Luxemburg, and New Zealand. These countries have experienced very high inflation, very sharp exchange rate changes, or very volatile output changes. These three economies are all very small.

6. One plausible inference with regard to the above result is as follows: after the 1960s, the industrialized countries are affected by some common, yet significant shocks, each to a 
different extent, so that their growth rates become less dispersed while the opposite is true for their exchange rate changes. Subsequent analyses lead to results which do not accord well with the inference. (See note 13.)

7. Similar suggestions have been made before, for instance, in Lothian (1986).

8. Unfortunately, there is no known good technique to identify points of regime changes for the problem, particularly since the time series samples are by no means large. The authors choose to split the period into the 1961-72, 1973-77, and 1978-84 sub-periods because in the later regression analyses this set of sub-periods gave the highest explanatory power measured by the percent variations of the dependent variable explained. The authors hasten to add that the empirical results reported later are not sensitive to the exact timing of the sub-periods. There were no substantial differences in the results when the break points are moved by one or two years, or when data points around the break years are dropped.

9. The variances in the second and the third periods seem to behave similarly, although the latter is often larger (which may be just a statistical artifact). The mean of the ratios of the variances in 1973-77 compared to the variances in 1978-84 is very close to one $(0.9996$ in the case of the real exchange rates and 0.7338 in the case of the nominal exchange rates). All but one of the ratios formed by the variances are not in the 5 per cent $F$-distribution significance region.

10. Both regressors are not put into one regression equation because they are too closely correlated. Also, the sample periods cannot be subdivided to examine regime changes because of degrees of freedom considerations.

11. The years 1961 and 1965 appear to be outliers. To test whether our results are caused by outliers, the influence diagnostics are examined. They reveal that 1961 is possibly an outlier. In the nominal exchange rate case, its Student residual is 2.94 , its $R$-student is 3.7 and its Cov ratio is 0.43 . The statistics in the case of the real exchange rate are similar. 1965 is less likely to be an outlier. However, it turns out that when the regressions are re-run without 1961, or without both 1961 and 1965, the estimated coefficients are still significantly negative. Indeed, in the case of the nominal exchange rate, the estimate becomes more significant when 1961 and 1965 are dropped.

12. The $w q$, variable is obtained from the 1986 IFS Yearbook.

13. It is straightforward to show that the decrease in the variance of $a_{i}$ and $b_{i}$ reduces the cross-country variance in output growth, while the increase in the variance of $w q_{t}$, an observation reported in note 20 , does the opposite. Therefore, the decrease in the cross-country variance in output growth during the flexible exchange rate period reported in Section II cannot be attributed to an increase in the magnitude of global shocks.

14. The results are not changed when the absolute value of the deviation of $b_{i}$ from the mean is used instead of the squared value.

15. Note that although the change in the dispersion of var $\left(e_{i t}\right)$ is not correlated with exchange rate volatility, the change itself is insignificant in magnitude.

16. The influence diagnostics are examined for the simple regression in each period. It turns out that there are no outliers except Japan in the 1961-72 period, which is not unexpected. When Japan is discarded, the sign of the estimated coefficient $b$ does not change. while its prob-value is lower.

17. Indeed, the country with the highest variance of output changes in the 1978-84 period, Canada, also has the lowest variance of exchange rate changes. It is well-known that the Canadian-US dollar exchange rate has a lower volatility because of the Canadian monetary authorities' concern with the dollar exchange rate volatility. Apparently, the consequence of such a policy is volatile output growth.

18. $\operatorname{Var}\left(e_{i t}\right)$ behaves like the variances of total output growth reported in Section II. Overall, its size does not seem to have changed significantly across periods.

19. The regressions are also conducted using the SDR instead of the US dollar to define the nominal exchange rate and using the percent change in the industrialized countries' CPI (as reported in the 1986 IFS Yearbook) instead of the US CPI to define the real exchange rate. The characteristics of the regression results are not changed.

20. $\operatorname{Var}\left(w q_{1}\right)$, the variance of the aggregate output growth of the group of industrialized countries, increased from 0.000108 in the 1961-72 period to 0.000347 in the 1978-84 period. The ratio of these two variances is significant at $F-5$ per cent.

21. Mussa (1981) derives his result by examining the minimization of the sum of an out-of-equilibrium cost and a price-adjustment cost. 
22. The regression is run without the 1978 data. This improves the significance level of the regressor, the mean inflation, in the last period (the prob-value is reduced by five times) while not having any other effects. The empirical results in Section III are regenerated without 1978 and no changes are found except unimportant changes in the numerical values of the estimates.

23. In the case of the real exchange rate, the estimate is 0.23 with a prob-value of 0.1 .

24. Note that this study does not directly use the mean of inflation or the variance of inflation as an explanatory variable. The reason is that these variables are influenced by output growth; thus, a simultaneous equation bias exists. The behavior of exchange rates is determined by many factors and is generally not as affected by output as is the case for inflation. Therefore, the variance of exchange rate changes is likely to suffer less simultaneous equation bias. This paper can be interpreted as using the variance of exchange rate changes as an instrumental variable to estimate the impact of price flexibility on output stability.

25. The mean output growth is regressed on the variance of nominal and real exchange rate changes in a manner identical to what was done in equations $\langle 6\rangle$ and $\langle 7\rangle$. The coefficient estimate is negative (approximately $=0.85$ ) and significant at the 5 per cent level only in the 1978-84 period. Further investigation of the relationship between mean output growth and exchange rate volatility is relegated to a future paper.

\section{References}

Baxter, Marianne, and Alan Stockman, 'Business Cycles and the Exchange-Rate Regime: Some International Evidence,' Journal of Monetary Economics, May 1989, 23: 377-400.

Darby, Michael R., AND James R. LothiaN, 'The International Transmission of Inflation Afloat,' in Michael D. Bordo, ed., Money, History, and International Finance: Essays in Honor of Anna J. Schwart=, Chicago: The University of Chicago Press for the NBER, 1989.

De Grauwe, Paul, 'Exchange Rate Variability and the Slowdown in Growth of International Trade,' IMF Staff Papers, March 1988, 35: 63-84.

De Long, Bradford, and Lawrence Summers, 'The Changing Cyclical Variability of Economic Activity in the United States, in R.J. Gordon, ed., The American Business Cycle: Continuity and Change, Chicago: University of Chicago Press for NBER, 1986 (1986a).

De Long, Bradford, and Lawrence Summers, 'Is Increased Price Flexibility Stabilizing?" American Economic Review, December 1986, 76: 1031-1044 (1986b).

Dornbusch, Rudiger, 'Expectations and Exchange Rate Dynamics,' Journal of Political Economy; December 1976, 84: 1161-1176.

Driskill, Robert, and Steven Sheffrin, 'Is Price Flexibility Destabilizing?', American Economic Review, September 1986, 76: 802-807.

Fisher, IRving, 'The Business Cycles Largely a Dance of the Dollar,' Journal of the American Statistical Association, December 1923, 18: 1024-1028.

Frenkel, JaCOB, AND Michael Mussa, 'The Efficiency of Foreign Exchange Markets and Measures of Turbulence,' American Economic Review, May 1980, 70: 374-381.

Friedman, Milton, 'The Case for Flexible Exchange Rates,' in Milton Friedman, ed., Essays in Positive Economics, Chicago: University of Chicago Press, 1953.

HaYeK, Frederick A., 'The Use of Knowledge in Society,' American Economic Review, September 1945, 35: 90-99.

INTERNATIONAL MONETARY Fund, International Financial Statistics Yearbook, 1986.

Jomnson, Harry, 'The Case for Flcxible Exchange Rates,' Federal Reserve Bank of St. Louis, Review, June 1969, 51: 12-24.

Kindleber Ger, CHARLes, 'The Case for Fixed Exchange Rates,' in The International Adjustment Mechanism, Conference Proceeding, Federal Reserve Bank of Boston, October 1969.

Kormendi, Roger S., and Philip G. Meguire, 'Macroeconomic Determinants of Growth, Cross-country Evidence,' Journal of Monetary Economics, September 1985, 16: 141-163.

Lothian, JAMES, 'Real Dollar Exchange Rates under the Bretton-Woods and Floating Exchange-Rate Regimes,' Journal of International Money and Finance, December 1986, 5: 429-448.

Marston, Richard, 'Stabilization Policies in Open Economies,' in Ronald W. Jones and Peter B. Kenen, eds, Handbook of International Economics, Amsterdam: North-Holland, 1985. 
Mussa, Michael, 'Sticky Prices and Disequilibrium Adjustment in a Rational Model of the Inflationary Process,' American Economic Review, December 1981, 71: 1020-1027.

MUSSA, Michael, 'Nominal Exchange Rate Regimes and the Behavior of Real Exchange Rates: Evidence and Implications,' in Karl Brunner and Allan Meltzer, eds, Real Business $C y c l e s$, Real Exchange Rates and Actual Policies, Carnegie-Rochester Conference Series on Public Policies, 25, 1986.

OECD Economic Outlook, Historial Statistics, Paris, 1985, and 1987. 